\title{
Transplanting institutional innovation: comparing the success of NGOs and missionary Protestantism in sub-Saharan Africa
}

\author{
Marian Burchardt ${ }^{1}$ (D) Ann Swidler ${ }^{2}$
}

Published online: 7 February 2020

C) The Author(s) 2020

\begin{abstract}
Viewing missionary Protestantism and non-governmental organizations (NGOs) as carriers of transnational institutional innovation, this article compares their successes and failures at creating self-sustaining institutions in distant societies. Missionary Protestantism and NGOs are similar in that they attempt to establish formal organizations outside kinship, lineage, and ethnic forms of solidarity. Focusing on institutions as ways to create collective capacities that organize social life, we trace the route whereby Protestant missionaries established congregational religion in Africa and identify social practices that made this enterprise successful but are comparatively absent in current NGO attempts to transform organizational life. Largely ignored by sociologists interested in institutional transformation, the history of congregational religion offers valuable sociological lessons about the conditions for radical institutional innovation. Its success was rooted first, in colonial missionaries' ability to enforce new ways of life on small exemplary communities; second, in local adaptations (African prophetic movements, Pentecostalism) that deepened and widened the social reach of congregational principles; and third in the incentives Protestantism created for propagating the congregational form.
\end{abstract}

Keywords Africa · Development · Institutionalism · Institutional transfer · Missionary Protestantism $\cdot$ NGOs $\cdot$ Pentecostalism

Marian Burchardt

marian.burchardt@uni-leipzig.de

Ann Swidler

swidler@berkeley.edu

1 University of Leipzig, Beethovenstr. 15, 04107 Leipzig, Germany

2 UC Berkeley Sociology Department, University of California, Berkeley, 410 Barrows Hall, Berkeley, CA 94720-1980, USA 
Over the last three decades, in many parts of the world but particularly in Africa, scholars have been impressed by the rise of two institutional forms: Pentecostal churches and non-governmental organizations (NGOs). Spreading across the continent at a rapid pace through church-planting and conversion, Pentecostalism has attracted ever larger numbers of followers because of its twin promise of modernity and spiritual protection (Marshall 2009; B. Meyer 1999), and organizational dynamics of independency (Englund 2003). Simultaneously, NGOs are mushrooming in Africa, aiming to transform societies to bring 'development'. This spread of donor-sponsored NGOs, however, contrasts starkly with widespread reports of their failures.

The success of Protestant congregationalism originated in the missionary intrusions from North America and Western Europe into societies of the Global South, making it one of the most striking examples of "successful" institutional transfer in the history of globalization. Contemporary students of international NGOs, largely critical of the failure of NGOs to create self-sustaining institutional change on the ground, have neglected the sociological lessons to be learned from comparing the NGO and missionary enterprises.

Despite the renewed focus on institutions in sociology, very little work examines how new institutions take root in new soil. This article compares a strikingly successful case of institutional transfer-missionaries propagating congregational Protestantism such that it became a self-replicating institutional form - in contrast to the much less successful efforts of contemporary NGOs to create sustainable local groups - participatory, democratic structures that will survive after the donors who initially fund them depart. Seriously examining the contrasting fates of these two efforts to create institutional forms for the realization of transcendent visions of transformation ("salvation" vs. "development"), we argue, offers broader lessons about the conditions for institutional innovation. We argue that missionary Protestantism's key institutional innovation was the introduction of congregational religion. We focus on institutions as sets of expectations, rules and symbols which create the collective capacities that allow people to maintain collective life, including forms of political authority from the chiefdom to the nation state, institutionalized forms of voluntary cooperation and organizational forms like the family (Scott 2008). We thus emphasize the actual ability of such institutions to organize social life on the ground, rather than the enactment of formal rules and structures "as myth and ceremony" (J. Meyer and Rowan 1977). This ability to reorganize aspirations, identities, and communities is what NGOs and other agents of institutional change aspire to, and this is where missionary Protestantism successfully made radical institutional innovations whose consequences still resonate today (Woodberry 2012). By comparing missionary Protestantism and NGOs we hope to specify more precisely what deep institutional transfer requires and to illuminate the complexly recursive processes by which institutional transfer ultimately "succeeds."

In a classic paper, Hall and Taylor (1996) identify three varieties of "new institutionalism": Rational Choice, Historical, and Sociological (referring to the Meyer school's focus on rules and recipes that both define and legitimate institutional structures such as the state [J. Meyer 1987] or the corporation [Palmer et al. 1993]). According to Hall and Taylor, rational choice institutionalists assume that institutions emerge from voluntary, self-interested agreements and are maintained by the functions the institutions serve. Historical institutionalists (see, e.g., Thelen 2004; Mahoney and Thelen 2010) account for institutional innovation by showing how innovators draw on 
elements of existing institutions and by emphasizing power: "Rather than posit scenarios of freely-contracting individuals, ... they are more likely to assume a world in which institutions give some groups or interests disproportionate access to the decisionmaking process; and, rather than emphasize the degree to which an outcome makes everyone better off, they tend to stress how some groups lose while others win" (Hall and Taylor 1996, p. 941). Sociological institutionalists explain the spread of institutional innovations in terms of legitimation: "organizations often adopt a new institutional practice, not because it advances the means-ends efficiency of the organization but because it enhances the social legitimacy of the organization or its participants" (Hall and Taylor 1996, p. 949). ${ }^{1}$ All these accounts, however, fail to describe why some institutional forms take root, thrive, and proliferate, while others may be transplanted but do not take root and spread. ${ }^{2}$

We begin from contemporary observations of a striking contrast between the vicissitudes of NGOs in Africa and the vitality of African churches (McGinnis 2007). Discussing a development project in rural Uganda, Jones (2012, p. 182) notes:

It was a typical story of development work in the region. The community structures supported by NGOs - such as village health teams - were active only for as long as the NGO was active, but did not do much when the NGOs were not around. .... Pentecostal churches manage to persist in rural Teso, while the committees and community-management structures introduced by NGOs are more episodic and ephemeral. The Pentecostal Assemblies of God (PAG) Church in Oledai has become an integral, physical part of the village, a feature as fixed as the longer-established Catholic and Anglican churches. The work of the KCPP (Katine Community Partnerships Programme) belongs to a history of projects, coming and going.

Other authors make similar observations, both about the failure of NGO and Community-Driven Development initiatives to leave a lasting institutional legacy (Pfeiffer 2004; Casey et al. 2012; Mansuri and Rao 2012, 2013; Scherz 2014) and about the vitality and deep local embeddedness of congregational religion in contemporary African life (Gifford 1994; Chabal and Daloz 1999).

While other scholars have drawn a comparison between churches and NGOs (notably the wonderfully titled "The Missionary Position: NGOs and Development in Africa" [Manji and O'Coill 2002]), this has usually been with a view toward criticizing NGOs for their missionary aspirations and their related deployment of power. Others have examined the relative success or failure of conscious efforts at "institutional transfer"the often-frustrated effort to import what are presumed to be superior aspects of the dominant Western institutional order-human rights (McGinnis 2007), gender equality

\footnotetext{
${ }^{1}$ This perspective is exemplified in Tolbert and Zucker's (1983) study of civil service reform in US cities, Boli's (1979) analysis of the increasingly expansive claims of modern constitutions, Strang's (1990) analysis of decolonization, and numerous studies of why nations adopt various treaties, legislative changes, and other innovations (summarized in Dobbin et al. 2007).

${ }^{2}$ Fligstein and McAdam (2012) have offered a powerful model of institutional innovation as the outcome of institutional entrepreneurship and struggles within existing organizational fields. They describe (p. 99) situations in which "powerful outside actors seek to invade an established strategic action field with the goal of altering the settlement as a means of advancing their own interests." They offer many useful insights, but they do not analyze situations in which the "invaders" introduce an entirely new institutional form.
} 
(Merry 2006), 'Weberian' state structures (Evans and Rauch 1999; McDonnell 2020), rule of law, transparency, etc.- - into the Global South (see Hammack and Heydemann 2009).

Given these striking contrasts between the triumph of Protestant congregationalism and the often depressing accounts of NGOs' performance, we suggest that there are crucial sociological lessons to be learned from the history of missionary Christianity. We follow up on the insight of one observer, W. M. J. van Binsbergen (2004:87) that.

the most powerful and most amazingly successful social technology implanted on African soil in the course of the twentieth century, has been the formal, voluntary or bureaucratic organization as defined along Weberian lines, which (despite all its malfunctioning) yet within a century has almost completely transformed all spheres of African life, from the state to education and health care, and which particularly has come to provide the dominant model of religious self-organization, among Christian churches, but increasingly also in the Islamic domain and even in the domain of African historic religion.

While we remain agnostic on the question of whether formal bureaucratic organization has become dominant in Africa, ${ }^{3}$ the missionary encounter's influence on the formation of religious "self-organization" in the form of the voluntary religious congregation is clearly a major sociological success. Today, $24 \%$ of the world's Christians live in Africa and the proportion of Africans who are Christians has risen from $9 \%$ in 1910 to $63 \%$ in 2010 (Pew Research Center 2012). ${ }^{4}$ Interestingly, both quantitative data and ethnographic evidence demonstrate that Christian belonging typically goes hand in hand not so much with canonized belief or standardized religious knowledge but with high levels of active participation and collective religious practice (Manglos 2010, 2011). Christians routinely see Sunday services, which may last anything up to $5 \mathrm{~h}$, as the most important event of the week, while for many the rest of the week is also filled with collective religious activities of all sorts. This is not to say that Christianity is the only "religious persuasion" which those who identify as Christians adhere to. Many studies suggest that parallel to their Christian lives many Africans engage in practices of ancestral worship and "African traditional religion." But congregational worship has become a major structuring force in African life. Indeed, the central sociological fact about African Christianity is not belief but a vibrant associational life (Gifford 1994). ${ }^{5}$ While in Africa there is a huge variety of churches with different historical origins, different forms of integration with pre-/non-Christian culture or faith traditions, different "beliefs" and spiritual practices, and seemingly never-ending cycles of schism and creation of new independent churches (Englund 2003), there is remarkable convergence across diverse Protestant denominations in the institutional form through which religious participation and collective practices are organized: the congregation.

By congregational religion we mean the model of voluntarist, self-sustained and independent religious associations or communities that has its historical roots in non-

\footnotetext{
${ }^{3}$ The extensive literature on corruption in Africa would suggest that the transfer of bureaucratic institutions and norms is very partial and incomplete. See Bayart 1993; Chabal and Daloz 1999; Smith 2003, Fisman and Miguel 2008; and Chabal 2009, among many others.

${ }^{4}$ See http://www.pewforum.org/2011/12/19/global-christianity-exec/, accessed 2/2/20.

${ }^{5}$ Gifford (1994, p. 533) claims that "participation in religious organization is the most prevalent form of associational life in Africa today."
} 
conformist (sectarian) Protestantism and is largely autonomous from competing logics (nationalism, ethnicity, tribal affiliation, etc.). While the successes and failures of missionary efforts to establish religious outposts in foreign lands have been extensively studied, there is a remarkable failure to note, let alone to examine closely, how congregational religion emerged as a reproducible institutional practice. In Africa, even more than in Catholic Europe, congregational religion was a cultural and organizational novelty. ${ }^{6}$

With our comparison, we do not suggest that NGOs and Protestant missions are generally similar institutions. As we show in detail, both differ with regard to the historical-political contexts in which they operate, their relationships to state authorities, and power over individuals. More importantly, they differ with regard to the nature of their main goals, with missionaries wishing to save souls and NGOs aiming to bring development. However, what they have in common and what justifies the comparison is that both offer transcendent and salvationist visions of transformation that is supposed to bring spiritual and material wealth, and that the promotion of these visions is contingent upon institutional innovations that carry them. Therefore, our point of departure is to comparatively explore their abilities to propel new self-sustaining institutions (congregations and local forms of participatory democracy) in order to draw more general lessons about the requirements of institutional innovation.

While focusing on Protestant missions as the originator of the fully voluntarist form of religious community and prototype for modern NGO activity (Stamatov 2013), we recognize that in African mission fields Catholicism with its parish structure and Islam with its mosques and Koranic schools share many of its institutional characteristics. Our own fieldwork in Malawi, South Africa, and Uganda, as well as our reading of scholars such as Laitin (1986) on Nigeria and others, suggest that in religiously pluralist African countries, and especially in those strongly influenced by Protestantism, adherents of competing faith traditions have a similar "congregational" understanding of their involvement in church or mosque. Nonetheless, there are usually (and how far this can be generalized is unclear) differences in the ways Protestant churches (versus Catholic churches and Moslem religious institutions) are financed. Protestant churches are generally built and sustained by the contributions of their own members. Many mosques, in contrast, are built with money from wealthy Muslim countries, and Catholic parishes are often funded by grants from European or other donors. ${ }^{7}$

\footnotetext{
${ }^{6}$ Scholars agree that before the arrival of Christian missionaries indigenous African religions ("African traditional religions") were largely rooted in forms of ancestor worship that served to consecrate lineagebased systems of authority and social obligation (Wilson 2009; Stuart 1979, p. 48; Comaroff 1985, p. 42), although the public healers and spirit mediums described by Feierman 1999 are an exception. The movements these leaders mobilized were however temporary responses to acute social distress.

${ }^{7}$ Islam and Catholicism also have distinctive institutional principles that differ from the Protestant congregational model, even in places (like many parts of Eastern and Southern Africa) where Protestantism provides the dominant model of religious organization. Both mosques and Catholic churches are understood first and foremost as sacred sites where people can perform required rituals, rather than as membership organizations along the lines of Protestant congregations. Catholic churches are at least intended to be hierarchical and organized in parishes, with priests appointed by the hierarchy and believers organized not as "members" of congregations (they are rather members of the "universal" Catholic Church) but in parish structures, where believers attend whatever church serves their parish. Most mosques also primarily provide a sacred site for required ritual activity, rather than being congregations constituted by their members. Where Protestantism provides the institutional model for religious life, of course, other faiths are compelled at least to some degree to take congregational form (see, e.g., Chen 2008 on Taiwanese Buddhists in the United States).
} 
While seeking to identify the general features and mechanisms of how congregational Protestantism took root and NGOs did not, we also recognize the internal empirical variation in these institutional fields. In the case of NGOs, we mainly focus on large international NGOs such as Save the Children that actually carry substantial legitimacy and power to promote transcendent visions. In the case of Protestant missions and churches, we are mainly interested in the role of Protestant Evangelical revivalist groups as the most successful actors in African mission fields as well as role of contemporary Pentecostal churches whose success is fundamentally based on and constantly reproduces the congregational model. Finally, while suggesting that the social dynamics around NGOs and, if to a lesser degree, Protestant missions show similarities across sub-Saharan Africa, our empirical focus is mostly on countries of Central, Eastern and Southern Africa, which share experiences of British (and German) colonialism.

Methodologically, our research proceeded in two steps: Through ethnographic and interview-based qualitative research in Malawi, South Africa, Botswana and Uganda we first established the tremendous contrast between institutional dynamics in fields of NGOs and Pentecostal churches. In order to account for this contrast, we then engaged in a systematic analysis of of secondary historical sources. Through this analysis, we identified elements that we deem critical to processes of institutional innovation and transfer: power, incentive systems, cultural adaptation and cultural translation. We then compared the ways these factors influenced the relative abilities of NGOs and Protestant churches to initiate self-sustaining reproduction.

\section{Congregational religion and NGOs as institutional forms}

From its European beginnings, Protestant congregational religion was organizationally innovative and dynamic (Eisenstadt 1978). Despite the authoritarianism of Calvin's Geneva and the political quietism of Luther's theology, the great innovation of Protestantism, and of sectarian Protestantism in particular, was to create the voluntarist community as an independent, reproducible institutional form (Weber 1946). E. P. Thompson (1963) memorably commented on this legacy in noting how Methodism taught the skills of self-organization that helped "make" the English working class. The same point has been made many times over in analyses of the revolutionary and disciplining effects of Calvinist Protestantism (Walzer 1965; Gorski 2003). However, despite the recognition of Protestant-origin "voluntarism" as a central component of Western modernity (see, e.g., Fischer 2010), there has been relatively little attention to the religious congregation as a central innovation of Protestantism: "the congregation as an all-purpose association with members who choose it, belong to it, and make contributions to it is actually a very Protestant model of religious organization" (Campbell and Putnam 2010, p. 30; see also Jepperson and Meyer 2011, pp. 64-65).

However authoritarian early sectarian Protestantism may have been, the break with church hierarchy; the emphasis on Bible reading, literacy, and the believer's own interpretation of sacred texts (Woodberry 2012); and the sectarian impulse to create an exclusive community of believers (Troeltsch 1992), meant that Protestant congregations, at least in principle, cut across existing social-organizational ties. One's neighbors, co-ethnics, or even family members might not be worthy of admission to 
the sect; traditional authorities might not behave as Godly magistrates (Walzer 1965); and groups of believers - even where, as in Elizabethan England or colonial America, they faced political repression-again and again felt empowered to create dissenting sects based on their own reading of the Bible.

Inspired by Nelson and Gorski (2014) we emphasize that congregational religion is a "modular form of social organization" that is horizontally replicable across vast territories and time spans. In Africa, the organizational elements of missionary Protestantism were bundled together in a form first developed in the mission stationchurches, schools, prayer groups, hospitals. These thus introduced, and to some degree defined, the elements of institutional modernity. Eventually the church congregation broke free to become a horizontal, voluntary community that united people independent of lineage, village, or clan ties, while hospitals and schools either remained under the purview of the missionary denominations (Frye 2013) or were incorporated into colonial and then independent African governments. Similar to the ways in which in medieval Europe Protestant congregations were instrumental in the unbundling of religious, political and territorial sovereignty, which the Catholic "parochial package" had interlinked, in Africa Protestant congregationalism mediated the creation of separate institutional spheres and new identities independent of tribe, lineage, or village. Over time, the congregation as a voluntary association of individual seekers became independent of the mission societies' control, turning into the independently replicable modular form we see today.

NGOs also aspire to generate new collective organizations, the democratic, participatory forms of "social capital" envisioned in myriad Community Driven Development projects (Fearon et al. 2009; Casey et al. 2012), or the ubiquitous NGO-promoted "community based organizations" or village committees (often required, as in World Vision's Area Development Projects, to be elected and to have fifty-percent women in their leadership). ${ }^{8}$ Indeed, much of the impulse behind NGOs is to transform local community life, so that the NGO's projects of social amelioration can indeed become "sustainable" (Scherz 2014). But reports from NGO researchers show that after the NGO and its funding depart, the organizational structures the NGO has created disintegrate. This makes the question of how Protestant Christianity implanted the autonomous organizational form of congregational religion all the more interesting from a sociological standpoint.

\section{Power, time, and ritual in Protestant congregationalism}

Congregational religion in Africa became an independent institutional form by establishing a social space outside traditional structures dominated by kin and lineage ties. We deal below with the historical stages by which missionary Protestantism was able to do this. We begin, however, with the basic structural factors that created differing constraints and opportunities for missionary Protestantism versus NGOs. The most important of these derive from the differing historical eras during which the two forms of institutional innovation expanded in Africa. Missionary Protestantism expanded in

\footnotetext{
${ }^{8}$ Stanczak et al. (2006), p. 22; see also Bornstein (2005) on World Vision's practice of "participatory rural appraisal."
} 
Africa from the mid-nineteenth through the early twentieth centuries, during the colonial period. NGOs, in contrast, proliferated since the 1980 s, in the era of independent African states. These differences in timing created differences in power, and thus in the ability of the two sorts of organizations to create practical, tangible and symbolic boundaries. Taken together, these factors constituted the primary mechanism through which congregational religion gained an institutional foothold on African soil, and also serve as vantage points for a comparison with NGOs.

\section{Institutional transfers and power}

This brings us to the problem of power - the sharply asymmetric situations in which both NGOs and Western missionaries attempted to alter belief and practice in distant societies. Many commentators have pointed out that NGOs, and Western altruists more generally, usually have vastly superior economic resources compared to those they try to assist, so they are very likely to be able to influence local people at least to pretend to want what the NGO is offering, to repeat back what the NGO wants to hear, and to submit to various monitoring requirements (Luke and Watkins 2002; Ghodsee 2006; Swidler and Watkins 2017). Despite substantial material carrots and sticks, however, even well-funded NGO projects fail to achieve lasting results. In one report after another, when the project funding ends, the local NGO collapses.

An important recent study by Casey et al. (2012) — a randomized trial of a three-anda-half-year Community Driven Development project in Sierra Leone which provided extensive training and support for new community decision-making processes as well as approximately $\$ 5000$ (equivalent to about $\$ 100$ per household) to fund community projects chosen by an elected committee - shows both the power of money (the village committees formed according to the rules the NGO prescribed, and they decided upon and built community projects with the advice and guidance of the NGO) and its limitations. At the end of the project, the 118 intervention villages did not differ from the 118 control villages in their decision-making patterns - the chief still made the decisions - nor in whether they allocated resources to collective vs. individual purposes. Again and again, reports on NGO projects conclude that attempts to introduce new structures for collective decision-making do not last, and, despite the rhetoric of "capacity building," NGOs leave no new institutional capacities behind. ${ }^{9}$

Like the NGOs, missionaries also offered material inducements: physical security, food, and new military technology such as firearms for chiefs. But they had access to greater coercive power than NGOs are able to employ, at least during the early phases of the missionary encounter, an encounter embedded in the establishment of colonial regimes and the violence it involved. ${ }^{10}$ First, in contrast to the early missionaries, today's NGOs operate within independent post-colonial states. However little some of these states may effectively regulate (or sometimes even know about) NGOs operating within their territory, NGOs typically still require at least the formal assent (or sometimes benign neglect) of the states within which they operate. During the colonial

\footnotetext{
${ }^{9}$ In a public-goods game, villagers in both intervention and control villages gave most of the money to the public good; chiefs still made the decisions in both intervention and control villages; and gifts from the project team went mostly to collective purposes in all the villages.

${ }^{10}$ Trinitapoli and Weinreb (2012, p. 20) point to the contrast between the missionary period and the present in terms of the perceived legitimacy of forcing (versus persuading) Africans to change their beliefs and behavior.
} 
period, missionaries often operated under the direct protection of, or even as allies of, the colonial regime and so their ability to establish outposts was ultimately protected by force. ${ }^{11}$ Indeed, frequently the missionaries, like the colonial settlers, were armed or accompanied by armed contingents (White 1987).

Routinely, missionaries had to negotiate with local chiefs and respond to their demands on the one hand, and respond to the demands of Colonial authorities (and sometimes settlers) on the other. Especially in Southern Africa, Christian missionaries were embroiled in frontier wars and armed conflicts over land and political power. In a typical pattern, tribal populations would either directly look for protection from other tribes' attacks in mission stations or missionary villages, or else seek to improve their relationships with colonial authorities through the mediation of the missions (VillaVicencio 1995, p. 53; Wilson 2009, p. 353; White 1987). Missions navigated amidst a complex politics of coalition-making, and mass conversion was often an important (by-) product of it (Etherington 2001). As was the case in Pondoland, when a chief converted, his people were converted as well. ${ }^{12}$ In East Africa, missionaries-because of their language skills - also often acted as mediators in negotiations between chiefs and colonialists (Strayer 1978). The missionary alignment with colonial and imperial political power thus set the terms on which "the missionary conversation" would proceed (Comaroff and Comaroff 1997). Especially for tribal groups who benefitted from missionary protection, it helped to create situations in which the power of the Christian god appeared immediately tangible as a result of which conversion "made sense" (Meyer 1997).

Second, and even more important, once a group of adherents had been drawn to live, work, and be educated at a mission station, they were directly under the governance of the missionaries, who could, and did, impose rules of conduct and decorum, and, as Elizabeth Schmidt (1992) describes in her history of Shona women in colonial Zimbabwe, forbid many traditional practices such as, for women, "brewing beer and dancing in ceremonies for the ancestors, ... becoming spirit mediums and diviner/ healers" (ibid., p. 148). As we see below, the mission station was only one phase of the missionary encounter in Africa. But its combination of material power and spiritual certainty, its ability to establish entire communities under the injunction to "win souls from heathenism, witchcraft and fear to a life of purity and freedom" (ibid., p. 147), established commitments to new beliefs and practices which could later become the basis for the embrace of new institutional possibilities.

Protestant missions defined their separateness through their organizational and ritual practices, through the importation of new symbols, and through the demarcation of symbolic boundaries: spatially, through distinct places (missions, churches), separate villages, and distinct economic activities; temporally, through Christians' use of the mechanical clock, the demarcation of weekdays from Sundays, and the Christian

\footnotetext{
${ }^{11}$ In the early missionary period, as White (1987) shows, missionaries such as David Livingstone could be abandoned, driven out, or killed when their trade goods and their arms ran out.

12 "Conversion" happened in a double sense. Since the chief was often the most direct channel of mediation to ancestral spirits, and thus himself a sacred figure, his conversion directly undermined or transformed the hold of the indigenous religious system. This transformation was reinforced when chiefs encouraged or even forced their subjects to convert to Christianity and enforced the missionary ban on traditional practices like puberty rituals, which undermined figures like traditional circumcisers, traditional healers, spirit mediums, and other mediators with the spirit world.
} 
calendar; socially, as Protestant missionaries' rejection of certain rituals, beliefs, aspects of authority (parts of customary law, chiefly authority, succession etc.) came to constitute converts, over time, as people of a community existing beyond the existing social structures.

NGOs, in contrast, cannot directly govern local communities, creating exemplary communities that transform individuals and enact an entire form of communal life. NGOs may aspire to radical transformation, but their activities are necessarily more piecemeal. They do not have military power, and except for their (usually small) paid staffs, they lack direct control over local livelihoods. ${ }^{13}$ NGOs are not, however, without material resources and cultural authority. NGOs draw legitimacy not only from their money and the wealth of the societies in which they originate, but from their claim to represent the standards of the larger cosmopolitan world that determines the value of the schools, credentials and other forms of human capital that might give access to formal labor markets (Frye 2012), NGO jobs (Swidler and Watkins 2017), and potentially even jobs in the Global North. They also frequently provide access to the officially authoritative abstract knowledge that embodies the prestige of globalized modernity (Frank and Meyer 2007). Despite these advantages, however, NGOs have not been able to translate their cultural prestige as representatives of cosmopolitan modernity into sustained institutional innovation.

\section{Effects of time}

Taken for granted by many commentators, another obvious contrast between NGOs and Protestant missionary activity is their differing temporal organization. ${ }^{14}$ Missionaries often devoted a lifetime to their missionary work, staying in one place for decades, mastering the local language, and learning enough about local systems of power and authority to form alliances with - or to circumvent or defeat - the critical players necessary for the success of their enterprises (Sundkler 1961). Indeed, the missionary outpost, whether a church, seminary, or mission station with its church, school, and clinic, was often a permanent enterprise.

In contrast, NGOs are notorious for their short-term, project-focused activities (Krause 2014). ${ }^{15}$ NGO-sponsored projects are rarely longer than two or 3 years, and often last only a few months. Donors want "leverage" from their funding. They want their projects to be "sustainable" (Swidler and Watkins 2009; Scherz 2014), and so they offer training to design and implement a specific intervention, usually involving training volunteers for no more than a few days and perhaps setting up a local committee. But then after the volunteers are trained, the NGOs and their funding depart, and the projects fade (Jones 2012). The ten-year (sometimes 15-years)

\footnotetext{
${ }^{13}$ An exception may be refugee and relief organizations, which effectively become the government of large refugee camps. These camps create their own institutional order, with its own regime of rewards and sanctions. Holzer's (2013) ethnography of a large refugee camp in Ghana finds that refugees become "wards of international law" (p. 840), who develop ingenious strategies for making claims within the camp. But neither they nor their governors (in this case the UN High Commissioner for Refugees) envision the camps as permanent communities.

${ }^{14}$ See Tavory and Eliasoph (2013) on the role of temporal alignment in coordinating action.

${ }^{15}$ In the 2005 Paris Declaration, recipient countries criticized donors for a host of failures, short-term, projectfocused giving chief among them.
} 
commitment World Vision makes to its Area Development Programs are the longest commitments we know of, but even then they do not create an enduring institutional infrastructure that could provide the scaffolding for new careers, aspirations, or identities.

Like most NGOs, World Vision's involvement is mainly in providing financing for specific projects, establishing a committee that is supposed to provide governance, and providing modest funding, much of it for training the myriad committees that spring up to access the opportunity for training with its potential for per diems and travel. This contrasts with the total transformation involved for early converts to mission life, who were schooled and ordained, and then often left much of their village life behind them (Etherington 1979).

Since NGO representatives almost never live in the villages where they locate their projects, or master local languages, they have little opportunity to discover what it would take to win over a local chief, to overcome quiet resistance, or to adapt their idealized governance structures to local conditions. Because they do not stay, NGO actors cannot fundamentally alter the calculations that local people make about what is a viable life strategy.

\section{Ritual competition}

To create a social form that was independent of the existing structures of authority organized around chieftaincy, lineage, and kinship - and spirit-divinership and witchcraft as their spiritual/moral cognates - missionaries had to make this new institutional form culturally meaningful in the perspectives of local people: African pastors, converts and congregants. Missionaries engaged in complex processes of modification, local adaptation, translation and indigenization to embed congregational Christianity in the African mission field. The missionaries succeeded in ritual competition, introducing distinct new rites for initiation, baptism, weddings, and funerals, but also Sunday services (Beidelman 1982, p. 190). They always acted with an eye on tactics, at times demanding exclusive participation, at times construing their rituals as combinable with inherited ones; the same holds true for organizational practices and the communities they constituted. Nonetheless, the history of the very gradual penetration of Christianity into Africa suggests the complex processes involved in such symbolic and ritual transformations.

\section{Christianity's vicissitudes in Africa}

The actual history of missionary incursion and its "successes" was by no means straightforward. Early missions in Africa were often entirely unsuccessful. Sometimes missionaries were killed, more commonly they died from tropical diseases and typically won very few converts. In most African regions, however, Christian missionary activities took place in the context of, and in several ways benefitted from, European colonial expansion. ${ }^{16}$ Over time, as Horton (1971, p. 86) observed with regard to Nigeria, "Europeans came to be seen as

\footnotetext{
${ }^{16}$ In West Africa, and also parts of Eastern Africa, missionary activities clearly predate colonial conquest. In Southern Africa, colonial expansion and Christian mission were more directly entangled, with colonial administrators encouraging the placing of mission stations at the frontier of settler colonies as means to facilitate contact. Simultaneously, there were missionary activities in yet unconquered territories, organized independently from 'political mandate.'
} 
symbols of power, and Christianity itself came to be seen as part of a larger order, comprising Western education, colonial administration, commerce and industry, with which everyone had henceforth to reckon" (on the same issue see also Beidelman 1982, p. 188).

While in many ways European colonialism 'opened the door' for Christian missionaries, missionaries in the field often came into conflict with colonial authorities. Typically, missionaries would work to build relationships of trust with chiefs and local communities in order start their work. In their negotiations with chiefs they would clarify the use of land and natural resources and the terms of the missionaries' engagement with local populations and also assure the chiefs that they had no intention of undermining their 'mundane' political authority (Comaroff and Comaroff 1997, p. 252). Yet since colonialism very much involved the rearrangement of existing power structures so as to fit its interests, the logic of colonial expansion and the logic of the mission were often at odds (Tyrell 2004). While missionaries needed safety, any political involvement beyond that could, and did, threaten their primary interests to convert, baptize, and save souls. ${ }^{17} \mathrm{~A}$ few missionaries went further, becoming champions of the cause of African political independence (Villa-Vicencio 1995).

Significantly, the most successful Protestant missions were not "delegations" sent with official mandates by established churches but rather privately organized associations of religious enthusiasts and revivalists belonging to non-conformist sects (Tyrell 2004). This is true for North German Lutherans and other German and Scandinavian missionaries, who almost always belonged to Moravian and Pietistic movements, as well as for the British Wesleyan Methodist Missionary Society and the ecumenists from the London Missionary Society (Wilson 2009, p. 349). In Southern Africa, Methodist missions were unable to supply the resources necessary for African Methodist groups which already in 1875 founded their own self-supporting schools and self-initiated missions (Etherington 1979, p. 115). Likewise, the American-initiated Congregationalist society became entirely self-supporting within a 5-year period through African contributions (ibid., p. 116). In total contrast, in the congregations established by the Anglican Mission in East Africa, native monetary contributions never provided meaningful amounts. Despite repeated rallies to secure donations from locals, "a selfsupporting church remained a myth" well into the 1950s (Beidelman 1982, p. 168). European paternalism remained strong despite the express aim to "convert and teach sufficient numbers of natives that eventually they would form their own autonomous congregations within the larger church" (ibid., p. 153) and the fact that Africans had shouldered the major part of proselytism for decades.

This dependence of Anglican congregations on a European established church is associated with the fact that still in 1959 Beidelman (1982, p. 200) found that "the most striking feature of local congregations is the absence of important group activities apart from common worship." ${ }^{18}$ Again, this was so despite the devising of a plan for local

\footnotetext{
${ }^{17}$ Sanneh (2001) argues that even at the height of nineteenth-century colonialism, African Christianity could reasonably be viewed as an ordinary part of world Christianity, and not as an imposition of colonialism.

${ }^{18}$ Beidelman (1982, p. 200) also notes of the Anglicans that "there are congregational committees established by the mission, but these have few members and are unsuccessful. A pastor's wife presides over a woman's group (mama chama) which teaches householdry at Saturday meetings in a school. An education committee composed of laymen ..., a hospital committee.... These groups have no power but diffuse limited information about mission policies and local needs. Membership in such groups is not prestigious but an onerous obligation to superiors within the church or to prominent men who have nominated one."
} 
pastorates in 1922 and the establishment of many offices and functions. Conversely, it seems that non-conformist missions such as the German pietists in the Gold Coast (B. Meyer 1997) had fewer difficulties with the promotion of congregational autonomy and self-sufficiency. For them, independence from temporal or political authority - first the European State, and later, in the mission field, chief, colonial corporation or colonial state - was often doctrinally crucial and contributed to the construction of the congregational model.

Fundamental, however, is the fact that step by step horizontal replication introduced new forms of local, indigenous agency in the missionary encounter while also reducing the control of whites over the process. As a consequence, Landau (1999, p. 10) argues: "African teachers played a larger role than missionaries in many places, and Christianity developed in ways missionaries did not understand."

The missionaries' alignment with the colonial apparatus was not immediately followed by the consolidation of congregational Christianity's institutional form. Indeed, while the missionaries early on brought ideas about individual salvation and some of the skills, such as literacy, that would undergird the creation of voluntarist congregational life, the mission station with its dependent population effectively ruled by the missionary authorities was quite different from the congregational religion that eventually emerged as the dominant institutional form in Africa. ${ }^{19}$

\section{Creating exemplary communities}

Mission stations, which would step by step grow into mission villages inhabited by mission communities (Strayer 1978), would typically comprise the missionaries' house, a church, a school building and workshops, and later also a medical dispensary or hospital. Early on, converts were expected to live and work at the station. They would thus be removed from their kraal or village in a conscious bid to separate them from the influences of "traditional culture" and traditional authorities. At the station, missionaries had extensive control over the new residents. Once disparate groups of Africans had gathered at the mission station they were dependent on the missionaries who could impose an entire, integrated way of life. Practices such as literacy and Bible reading, wearing Western clothing and bathing with soap, and monogamous marriage, along with the abandonment of traditional rituals (Stuart 1979; Comaroff 1989, pp. 673-674; Schmidt 1992) created a powerful symbolic boundary that set off the community of converted Christians from the wider society. The movement to the station therefore instantiates the discursive distinctions between past and present, African tradition and Christian modernity, and backwardness and civilization, that fundamentally organized the hermeneutics of the missionary encounter (Comaroff and Comaroff 1997). ${ }^{20}$

\footnotetext{
${ }^{19}$ The finding that connections to political authority alone rarely produce sustainable institutional forms suggests an important parallel to NGOs (see Manji and O'Coill 2002). Woodberry (2012) emphasizes the Protestant commitment to literacy as critical to its influence on larger institutional outcomes, like democracy. The authoritarianism of early Protestant mission stations and the eventual transition to vibrant voluntarist institutions parallels developments from other forms of early authoritarian Protestantism (see Walzer 1965 on Calvinism in England; Bushman 1967 on Puritanism in America).

${ }^{20}$ For a painfully vivid picture of these distinctions, see Tsitsi Dangaremba's brilliant portrayal of her Zimbabwean mission girlhood in her novel Nervous Conditions (1988).
} 
John Comaroff (1989, pp. 673-674), analyzing the missionary encounter with Griqua and Tswana peoples in early nineteenth-century South Africa, makes vivid how missionaries sought to create an exemplary model of a coherent way of life, a "total reconstruction":

... far from limiting themselves to religious conversion, the evangelists set out, at once, to (1) create a theater of the everyday, demonstrating by their own exemplary actions the benefits of methodical routine, of good personal habits, and of enlightened European ways; (2) banish "superstition" in favor of rational technique and Christian belief; (3) reduce the landscape from a chaotic mass of crude, dirty huts to an ordered array of square, neatly bounded residences (with rooms and doors, windows and furniture, fields and fences), enclosure being both a condition of private property and civilized individualism, and an aesthetic expression of the sheer beauty of refinement; (4) recast the division of labor by making men into hardworking farmers and bringing women "indoors" to the domestic domain, much along the lines of the English middle-class family; (5) encourage these families to produce for the market by teaching them advanced methods, the worth of time and money, and the ethos of private enterprise - the explicit model being the late British yeomanry (see above); all of which (6) demanded that Africans be taught to read and reason, to become self-reflective and self-disciplined. It followed, as axiomatic, that "heathen" society would be forever destroyed.

Making a similar observation of nineteenth-century German pietistic missions among the Ewe at the Gold Coast, Birgit Meyer (1997, p. 158) argues that the objects of Christian material culture - clothes, furniture, building materials, money etc.-were fundamental in shaping Africans' perceptions of Christianity and the meanings of conversion: "Western education, new clothes and money clearly implied each other and constituted a newly evolving nexus of "civilization."”

But why would Africans be attracted to convert and live at the mission station? Horton (1971) and others suggest that during the early period conversion in high numbers was rare, political and military circumstances were key, and motives varied. Converts were refugees escaping military raids, women escaping unwanted marriage, subordinated chiefs and their subjects, or generally less affluent people in search of alternative ways of achieving status (Strayer 1978, p. 3).

Newly emerging aspirations to schooling, education, and literacy were entangled with the desire for consumer goods, while purchasing these goods was made possible through the salaries converts earned through their employment at the mission stations. In the course of 20 to 30 years, the isolated outposts turned into trade centers and thus "became focal points for new associations of Africans" (Strayer 1978, p.52). Thus the introduction of Christianity, a money economy, commerce, and Protestant ethics of rationalized work and personal discipline coalesced spatially and socially, and were all articulated at the mission station. The aesthetic practices (clean, ironed clothing, furnishings, etc.) made possible through the purchase of consumer goods were also key to demonstrating and validating membership in the Christian community and therefore served as markers of the symbolic boundaries of the congregation. What is 
more, converts also began to contribute some of their income to the congregation (B. Meyer 1997, p. 165), a key to achieving "sustainability."

The drawing of symbolic boundaries facilitated the emergence and consolidation of congregational religion in three interlinked ways: first, missionaries successfully engaged in a politics of ritual competition, introducing distinct kinds of initiation to mark membership. They did this tactically, at times in an exclusive fashion whereby compliance with their rules became a condition for membership, at times more flexibly, allowing inherited rituals. Second, this had implications in terms of the boundaries between Christian and non-Christian with regard to social obligations. Non-compliance with tribal rules of succession and refusal to participate in certain rites of passage and forms of ancestral worship would, sometimes directly, exclude people from kinshipbased social relations, sometimes also from chiefly authority, and from related channels of distribution of wealth. This, in turn, would "free" people to devote time, resources, commitment, and loyalty to "their congregation." 21 Third, converts adopted a series of aesthetic practices, for instance, with regard to cleanliness, clothing, and the construction of houses and furniture, that served as visible markers of distinctness and belonging. These three aspects powerfully combined to carve out a distinctive Christian identity, which could in turn provide the basis for an autonomous form of collective life.

At the mission stations we thus see the emergence of congregational life, which initially depended on financial and other forms of support provided by foreign mission societies. ${ }^{22}$ A crucial step in the development of autonomous congregational life was sending African pastors or teachers from the mission stations to the villages where they would build Christian schools, or they would build "daughter" stations in proximity to rural populations. This led to the multiplication of the congregational model as it initiated the horizontal replication of its modular elements. The missionaries' determination to proselytize, to bring as many souls as possible to the true faith, led the missionaries to send trained preachers and teachers out to found their own churches or schools.

\section{Translating collective meanings}

Studies of the spread of Christianity in Africa usually emphasize the centrality of the introduction of scripturally based religion: questions of language and translation, literacy, and the power of the Word (of the Bible). For the deep absorption of a new model of collective life, it certainly mattered that the central sacred object, the Bible, was translated into local languages, that those languages were redefined as written ones, and that local people were trained both to read and to preach the Bible and its teachings. ${ }^{23}$ The way the Bible and other religious concepts were translated, however, contrasts with the kind of translating and the kind of "training" that the NGOs do.

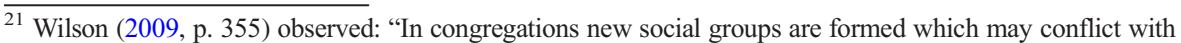
existing kinship groups. Converts are taught loyalty to their faith must take precedence of loyalty to their chief."

${ }^{22}$ It sometimes, however, relied on forced labor of Africans to support itself (White 1987).

${ }^{23}$ In the case of Zululand, Etherington (1979, p. 113) notes that "portions of the Bible were translated into the Zulu vernacular and printed as soon as missionaries acquired a reasonable understanding of the language." The earliest known translations into Southern African vernaculars are those of Robert Moffat starting in 1822.
} 
Landau (1995), as well as Horton (1971), Beidelman (1982), and Comaroff and Comaroff (1997), describe how in the missionary conversation missionaries wouldliterally and directly-draw on the terms and concepts of African vernaculars in their attempts to translate words such as God or Highest Being. They would then build and translate the Christian story around these key vernacular concepts. Horton (1971, p. 100) describes how "Christian proselytization in Yorubaland [promoted] the identification of the Christian God with the indigenous supreme being Olorun, and the presentation of Christianity as the 'true' way of contacting this being." He then observes that "missionaries all over Africa have usually striven to discover the name of the indigenous supreme being, and, where successful, have then gone on to tell the people of his 'true' nature." Likewise the missionaries would refer to indigenous practices they observed among Africans when they resembled Christian forms such as prayer or confession and thereby enter into recursive processes of appropriation and re-appropriation of meaning. In many instances, these practices facilitated the ways in which, for instance, the Yoruba of Southern Nigeria could pray to a higher being for rain, health and children, and come to construe Christianity as the supreme way of accessing the power this self-same higher being (Horton 1971). In other words, the very practice of translation allowed the missionaries, in conjunction with their African interlocutors, to tap (or get access to) important African, that is, indigenous "sources of the sacred" (Swidler 2010).

This sort of "deep" translation, which transforms and re-appropriates meanings as it "translates" them, contrasts sharply with what we know of NGO practices in this regard. We have already said that those who run NGOs rarely themselves have lived for extended periods in the societies they seek to influence, and they almost never learn local languages. Indeed, when one of the giant international NGOs, like PSI, launches a campaign to prevent HIV transmission or encourage family planning, such campaigns are often centrally designed, with the same script and the same graphics carried from place to place, and then translated into local languages by paid consultants. ${ }^{24}$ Several analysts (Pigg 2005) have pointed out that this leads to stilted language, distanced from local understandings, as when local terms for sex or for lovers of various sorts are replaced with terms like "multiple concurrent partners" or "unprotected sex." Even more striking is the tendency to retain key terms in their original English or French, so that AIDS is called "Edzi" or "Sida" in local languages, and even those speaking Shona or Yao will sprinkle their talk with the English terms "gender" or "multiple partners" or "FGM" (Female Genital Mutilation) even when describing their own experience. McGinnis (2007, p. 410) attributes the failure of many democracy and human rights NGOs to the fact that "very little effort has gone into translating the fundamental concepts of liberal democracy into local languages and symbolic forms fully understandable within local cultures." Thus the intimate linguistic fluidity which led missionaries to adapt powerful local concepts (and the gods that went with them) to convey the power of their own terms is replaced in NGO-speak with a flood of acronyms and loan words, as flat and opaque to the locals as they are to their NGO sponsors. ${ }^{25}$ That

\footnotetext{
${ }^{24}$ Examples of standard messages transposed to different countries can be found in the videos, posters, and radio spots catalogued at: http://misaccess.psi.org/bcc_catalog/web/search.html, accessed 2/25/2014.

25 This is true even in religious settings where faith-based organizations engaged with development and health programs adopted globally circulating rhetoric (see Dilger et al. 2010).
} 
key sacred terms of development discourse such as "human rights" and "gender" remain un-translated in vernacular speech suggests that they are indeed construed as in some way transcendent in local perceptions. But usually this transcendence is organized around fantasies about the modernist (Anglophone) cosmopolitan world, and aspirations of membership in it, which is simultaneously desired and alien, and certainly less easy to obtain than membership in the Christian cosmopolitan world. ${ }^{26}$

The patterns of "deep translation" the missionaries engaged in, in contrast, had much more powerful yet contradictory effects: on the one hand, they allowed Christian missionaries to "initiate the conversation," to become instrumental in local people's quest for rain, fertility and protection against misfortune, and to channel the binding energies of the sacred into new networks of sociality in which they would be central figures. On the other hand, these translations certainly undermined, albeit only temporarily, attempts to differentiate the Christian religion as something apart from the existing social, moral and cosmological structures of African societies.

The deeper importance of translation, literacy and the Bible lay in the collective organizational practices they made possible, which in turn helped to sustain congregational religion. Reading and studying the Bible became one of the fundamental activities of members of a congregation. Again, these practices thereby helped to shape the boundaries of the congregation and provided direct motivations for people to participate and sustain it. Reading the Bible became, of course, part of the Sunday service, but it was also increasingly organized through Bible reading circles whose members would meet, sometimes several times, during weekdays (Wilson 2009, p. 351). Bible study as ritual contributed to the sacralization of institutional purposes, and became-together with prayer, testimony, and singing-a central organizational practice of church worship services. Similar to the Bible reading circles, we see the emergence of permanent prayer groups (Gaitskell 2000) that fostered congregational life.

\section{African appropriations of missionary Christianity}

While organizational practices were key for buttressing a sustainable form of congregational religion, over the last 150 years several large-scale religious movements reoriented Christianity in Africa. These were crucial for transforming Christianity into an African institution. The first of these departures concerned issues of African leadership, and more generally African agency within the field of power relationships in the missionary encounter. The result was the emergence in the late nineteenth century of what in Nigeria was called the "African Church Movement." Horton (1971, p. 86) writes: "Yoruba congregations resented the European monopoly of church authority; and their resentment was exacerbated by strongly authoritarian patterns of church organization." In response to this situation, some churches broke away, came under the leadership of Yoruba bishops and developed their own organizational forms, which mixed traditional and missionary elements in a syncretistic fashion while sticking to Christian orthodoxy with regard to belief and doctrine.

\footnotetext{
${ }^{26}$ Following Horton (1971), many scholars have emphasized that the attraction of world religions in Africa lay in their larger scale, larger sense of communion, "which stood in vivid contrast to the narrow confines of traditional society" (Stuart 1979, p. 55, see also Englund 2003).
} 
Moving from South Africa to other countries of southern Africa, we find similar collective attempts to increase Africans' control over the organization of religious life starting in 1892 with the so-called "Ethiopian Churches" (Sundkler 1961, pp. 56ff.). ${ }^{27}$ Also termed “African Independent Churches," these churches emerged through secessionist breakaways from mission churches with the main intention of countering forms of proto-apartheid, the power of white missionaries to limit Africans' upward mobility in church hierarchies and to maintain or intensify racial segregation in church life.

Economic factors added to Africans' quest for church leadership positions. When colonial authorities blocked opportunities for Africans in the entrepreneurial sphere, and, more importantly, when fears of rising African nationalism led colonial powers to start excluding Africans from positions in the colonial service, demands for positions in the missionary churches increased (Etherington 1979, pp. 120-121). Importantly, these Ethiopian churches retained the institutional and sociocultural forms of mission Christianity while infusing them with ideologies of self-determination. In a few cases, this reflected tribalist appropriations in that chiefs became church leaders; more often, Ethiopian churches became carriers of ideologies and theologies of pan-African, post-tribalist Black liberation and turned into arenas for the promotion of a biblical "embryonic nationalism" (Comaroff 1985, p. 175).

Just a few decades later, another secessionist Christian movement emerged, which would provide a more radical departure from missionary Christianity. Reflected, among others, in Southern Africa's "Zionist" or "Christian independent" churches (e.g., Cabrita 2014) and Nigeria's Aladura churches (Peel 1968), this appropriation of Protestant Christianity would break with the limitations missionary orthodoxy and orthopraxy put on African religious creativity. Unlike the earlier African independent churches, these churches introduced new beliefs and doctrines on the basis of new prophecies. Also known as "healing churches," they put great emphasis on their prophets' abilities to identify the cause of this-worldly misfortunes and to remedy them through divine healing, drawing on a complementary mix of worship of the (Christian) Holy Spirit and ancestral spirits (Kiernan 1995, p. 126). The similarities between the Zionist prophet and the "traditional" African diviner are striking.

While the cultural meanings and some ritual practices in the Zionist churches differed sharply from those of the missionary churches, the institutional form of voluntarist congregations remained intact, and was even strengthened. First, religious life in these churches continued to be organized around ministers (as leaders of a congregation of a voluntarily assembled group of followers) who are to some degree supervised by a denominational hierarchy. Congregations also remained largely independent of - and potentially an alternative to - clan, village, or lineage ties. These churches thus absorbed many African religious elements, but they were not absorbed by African social structural patterns. Second, insistence on the authority of the Bible and on prayer and Christian revelation in healing activities created continuity in the collective organizational practices that contributed to constituting community life. Third, and importantly, the Zionist congregations began to coordinate the provision

\footnotetext{
${ }^{27}$ The term "Ethiopian" in the name is a biblical reference. The word "Ethiopia" appears in Psalms and the Acts of the Apostles and was taken to reflect a long-standing African Christian dynasty.
} 
of some social and economic support for their members (Beidelman 1982, p. 166). As Kiernan (1995, p. 125) perceptively argues,

... the Zionist congregation caters for the individual in much the same way as the kinship group once did, although it is manifestly not a kinship unit. The kinship group relied on marriage and descent for its continuity. The Zionist congregation largely fails to retain the allegiance of its children, and finds recruits from among adults troubled by misfortune in the population at large.

In fact, over the following decades (re-)conversion and recruitment into new churches became the generalized mode of constituting congregations in many parts of Africa, while most traditionalist reproduction of the church community via birth or descentbased membership was undercut. Struggles for independent leadership and the multiplication of congregations and churches through schisms became the norm.

This competition for congregants signaled the dominance of the voluntarist congregational model. From the late 1970s onward, the tremendous spread of Pentecostal and Charismatic Christianity moved African Protestantism in an even more voluntarist direction. The Pentecostal stress on conversion as dramatic enactment of radical personal transformation by "making a complete break with the past" (B. Meyer 1997) added a decidedly subjectivist and individualist notion to the voluntarist conception of congregations, in which the community is constituted by the voluntary choices of its members. In Pentecostalism, these "breaks" are construed as breaks not only with sinful individual life, but also with what Pentecostals view as sinful (collective) traditional practices and beliefs that expose people to the dangers of misfortune and witchcraft (Jones 2012). Pentecostals thereby assign "African tradition" to the past. By "tradition" they mean social obligations based on kinship, ancestral cults, and relationships to traditional healers and diviners, which they often proscribe. Conversely, they dramatize people's individual abilities to make "their choice" for Jesus. It is a taken-for-granted part of that choice that converts and adherents sustain their religious communities through tithing and voluntary activism. Pentecostalism thus constitutes the ultimate "success" of the voluntarist congregational model in that it articulates an individualist conception of participation with mechanisms that assure its horizontal reproduction.

\section{Institutions and incentives in NGOs versus Protestant congregationalism}

Congregational religion differs most sharply from NGOs in the basic incentives each creates. Without entering the fraught debate over the role of religious competition in stimulating religiosity (Finke and Stark 1992; Warner 1993; Chaves and Gorski 2001), most Protestant clergy in Africa can support themselves financially only to the extent that they can build and retain a congregation. From the missionary period onward, seminary training and ordination have been a license to go out and found a congregation. In the contemporary period, Pentecostalism makes it possible for anyone who feels the power of the Holy Spirit to begin to gather a congregation. Thus it is not so 
much denominational competition as congregational competition and churches' reliance on their members' voluntary contributions that shape the congregational incentive system. $^{28}$

In contrast, as many observers have pointed out, the incentives for NGOs are to satisfy their funders, usually large international donors (see, among many others, Bartley 2007; Wallace et al. 2007; Cooley 2010; Morfit 2011; Jalali 2013). NGO activists may complain about the need to submit reports and account for funds in order to keep their funders satisfied, but their livelihoods typically depend not on satisfying their constituents, but on satisfying their donors. The paid staff members are paid not by the beneficiaries they are supposed to assist, but by the donors who "subcontract" to the NGO the job of helping beneficiaries (Watkins et al. 2012; Krause 2014). The incentives that drive institutional dynamics in both types of organizations are thus inverted: while pastors largely draw their wealth from below (the congregations on which they depend), NGOs draw their wealth entirely from above (their external sponsors).

\section{NGO training as an unsustainable practice}

The success of missionary seeding of "daughter" schools and congregations stands in sharp contrast to NGOs' efforts to "train" people to go back to their villages and train others in HIV-prevention, climate change, early-childhood education, or other skills. Despite the fact that in some ways the NGO model draws from the missionary imaginary (Stamatov 2013), the NGO trainings do not become self-sustaining. One reason is that training is seen as mainly technical rather than transformative. It does not directly promote creating a new community that will commit its members to a new form of life, as was the case for missionary communities (Comaroff 1989; Freeman 2012).

NGOs' trainings also do not create incentives that make them self-propagating the way the missionary congregations do. This is a matter both of the incentives for those who would train others (the structural equivalents of Christian pastors or teachers) and of the incentives of potential "congregants": those whom the NGO might hope to train and thus transform. Those who initially receive training from an NGO, and who might aspire to go back and train their fellow villagers, face distinct challenges, which are highlighted by contrast with the incentives one trained as a pastor or religious teacher might face.

The most striking contrast between Protestant church planting and NGO training is the very different incentives for those who are trying to spread their message to others. The missionary training of pastors was in effect a license to earn a livelihood by gathering a congregation, whose members undertake the obligation to support their pastor. In contrast, normally trainings are expected to provide some small material benefit for their participants: allowances and per diems for top "trainers of trainers," smaller per diems and travel money for those further down, and at least refreshments for villagers who might take time off from their gardens to attend a training (Burchardt

\footnotetext{
${ }^{28}$ Englund (2001, 2003), like other researchers, makes clear that even when external support from foreign missionaries is available to African churches, that support is for "church planting" and depends on the pastor's ability to create a vibrant congregation.
} 
2013, p. 148; Swidler and Watkins 2017, pp. 172-175). Thus there are costs, rather than rewards, to those providing the training. The one exception to this seems to be the relative success of AIDS youth clubs, which go around to villages performing AIDS dramas. It is not clear how much this happens after the youth club is no longer funded, but the pleasures of visiting and making contact with youth from other schools and villages (not unlike the ways congregations send their choirs and praise teams out to other churches) may provide enough intrinsic rewards to motivate this sort of activity.

Second, what training transmits, even if over several sessions, is understood to be a permanent transfer of information, or self-improvement techniques, that should in principle be self-sustaining (Swidler and Watkins 2009). So once the training is over, there is no continuing activity that requires continuing participation, in the way that even after conversion, religious worship and the powerful rituals it provides are required to maintain the believer's connection to divine power. Precisely the view of training as "sustainable" because it does not require continuing inputs from donors means that once the training is completed, the participant is done, "trained." The Christian convert, in contrast, is at the beginning of what is understood to be a lifelong quest for salvation - or in the shorter term for moral self-improvement - for which continued participation in the religious ritual, and the support of the congregational community, is essential. Christian communities over two millennia have developed definitions of their religious quest that require continuing participation and devotion from their members (the requirement for weekly confession, for example, in the Catholic Church), for taking the sacraments, and even for less sacramental churches, the need to drive out evil spirits, combat backsliding, confess, or simply reawaken one's commitment to Jesus. This is accompanied by centuries-long development of powerful religious music and ritual symbols, along with a powerful transcendent promise. NGOs also offer an alluring promise - that of connection to the rhetoric and the symbols of modernity. But without a definition of a continuing need for a collective context to reinforce the modern identities NGOs promise, these organizations fail to sustain or replicate themselves.

Third, churches offer cosmopolitan connections, while NGOs' own ideals of creating democratic participation replicate rather than offer an alternative to the constraining localism of village life. Robin Horton and J. D. Y. Peel point out that one of the most powerful appeals of Christian conversion was that it linked believers to a wider cosmopolitan community, to a universal Christendom (Horton 1971; Horton and Peel 1976). But Christian congregations, especially Protestant ones, tend to be cosmopolitan in another, more practical sense as well. Precisely because it is freely chosen by the believer, a congregation in a village or town will typically draw people from several villages, or from different neighborhoods, clans, or communities. Thus the congregation gives its members access to sources of information, friendship, and support from outside their own communities. This interest in new people and places is extended further by the frequent practice of sending youth choirs, praise teams, pastors, and church committees to visit other churches, sometimes in neighboring communities, but frequently farther afield. In contrast, the dominant model of institution-building in the NGO world, emphasizing community participation, envisions new, more democratic, participatory structures being nurtured in the communities where people already live, farm, and work. Here the striking contrast is between the NGO-sponsored training and what is supposed to happen when those being trained return to their villages. The 
training, perhaps at a motel or guest house, might bring together representatives from several villages to be trained together to combat AIDS, or raise awareness about climate change, or become sensitized about gender violence. Aside from the material incentives involved, those fortunate enough to be invited to such a training enjoy the opportunity to meet others, to develop new friendships, or simply to learn about things happening in other places. But when those who have been trained return to their villages hoping to train others, they have no such new, potentially broadening sociality to offer. Indeed, the vision of the NGO sponsors is that the newly enlightened villagers will return to their "community" to bring back a new message. The trained volunteers, however, long to escape the village, not to become further enmeshed with those with whom their lives are already deeply intertwined.

Fourth, there is the content of the message. The NGOs do of course offer something powerfully legitimating and desirable, at least to the stratum of aspiring but insecure, educated youth who form the core of their "volunteers" (Englund 2006; Swidler and Watkins 2009): access to the vocabulary and modes of thought associated with global modernity (J. Meyer et al. 1997; Frank and Meyer 2007). But in this respect, the NGOs are less distinctive, or have less of a monopoly on the transformative ideology they offer than churches do. For villagers who aspire to be more "developed" or "enlightened" (these are local terms, see Englund 2006 on "enlightenment"; also "évolué" in French Africa) or educated youth who have yet to acquire a foothold in the formal economy, the formalized knowledge NGOs offer, and the modern identities they underwrite, can be enormously appealing. But these modern values and identities pervade the modern sector of African societies, especially the educational systems, but also the formal economy, the technocratic parts of government, the professions, the international organizations, and to some extent even the media. Thus NGOs do offer a kind of transitional experience for those aspiring to move up out of the village and its culture, or to sustain their identity as members of the educated middle class in the difficult period between leaving school and finding a toe-hold in the formal economy. For some, volunteering and repeatedly participating in NGO trainings provides a trickle of livelihood, while they seek formal employment, perhaps in the NGO sector. But precisely because it is the dominant culture of global modernity, this affirmation of a modern identity does not have the exclusive hold that the elaborated notion of Christian salvation, and its supports for continuous personal discipline and individual striving, alongside community effervescence, can provide.

\section{Conclusions}

The contrasting fates of Protestant congregationalism and NGO developmentalism in Africa suggest wider lessons about the conditions for the transfer of institutional patterns from one social context to another. The literature on the "new institutionalism" frequently emphasizes "decoupling" - the adoption of formal institutional rules without any necessary effect on practices on the ground. Another view would take what happens on the ground more seriously, but note that the imported institutional forms are often subject to a sort of reverse colonization, in which imported institutions are reappropriated and adapted to local norms and practices, appearing as clientelism, corruption, or "elite capture" (Smith 2003; Swidler 2009; Mansuri and Rao 2012). 
These limitations suggest several larger points about what institutional transfer-and perhaps the creation of viable, new institutional forms more generally-may require:

Power The colonial encounter, like the imposition of new institutions in post-WorldWar-II Japan and Germany (Jacoby 2000), involved the power of conquerors to impose new institutional rules and enforce them on subjugated populations. While missionaries often (not always) used gentler means, we have emphasized that those early converts who found themselves dependent on the mission station could be persuaded and coerced to adopt not one or two elements of Protestant Christianity, but an entire way of life. Sociologists have written about the "embeddedness" of the economy in the rest of social life (Granovetter 1985). One important school of institutional theorizing, best exemplified by Hall and Soskice's Varieties of Capitalism (Hall and Soskice 2001), emphasizes the multiple interdependences of the varied institutions that constitute a modern economy. Both these lines of argument underline our basic point that it is very difficult to introduce a new institutional form (in this case participatory, democratic, empowered community governance), as NGOs try to do, without the power to change the many other institutional and cultural elements that constitute the existing social order. The missionaries had the advantage, at least in the early mission station, of being able to work out a more-or-less complete cultural-institutional model, even if that model still had to find a way to sustain itself.

Cultural adaptation As our extended description of the various phases of the Protestant missionary encounter makes clear, Christian conversion did not spread widely in the first decades of the missionary period. Christianity, and especially Protestant congregationalism, really spread only when two additional elements were added. First, a new incentive system began to take root, in which training as either a pastor or a school teacher began to offer an attractive career for Africans. Especially as educated Africans were forced out of the colonial civil service, they began to demand positions in missionary organizations, increasingly filling the ranks of preachers and teachers. This then created incentives to found more schools and churches. Perhaps the most crucial difference between NGOs and Protestant congregations is that for Protestant congregations, the basic incentive system reproduces the institutional form, while for NGOs, the basic incentives undermine it. Training in a missionary seminary or school was a license to go out and found one's own church or school, so that the ability to earn one's living depended on one's success in recruiting congregants or students. NGOs, as their sponsors have repeatedly found, create incentives to move up and away from the local community, moving from unpaid village volunteer to-if a volunteer is successful-paid staff member living in town or in the capital. Donor money turns NGO participants away from trying to appeal to their fellows and toward pleasing their funders. The institution the NGO thus reinforces is not participatory governance of the village community, but formal employment in the NGO bureaucracy. The NGO ideal of sustainability further weakens the likelihood of NGO organizational models becoming institutionalized. In NGO understandings, "sustainable" projects provide only short-term funding and rely on volunteer labor, so there is no danger of creating "dependence" (Scherz 2014). 
Incentives Our findings also provide insight into the role of incentives in the creation and reproduction of institutional forms. One model of how institutions come about emphasizes their gradual evolution (Ostrom 1990; Thelen 2004). Over time, an institutional arrangement becomes more deeply embedded, more institutionalized, as more groups or individuals come to see the advantages of pursuing their interests through it. In the case of the complex systems of protecting the commons (sharing limited supplies of water for example), the origins of the institutional arrangements are lost in the mists of time, but they continue to "work," because they regulate access to a common pool resource and because those who manage the system have both rewards (continuing access to the resource) and sanctions available. In the case Thelen (2004) describes, more and more groups "buy in" to the German system of vocational education as they find both that they need to protect their interests and that they can pursue their interests in its terms. The gradual consolidation of the congregational model of Protestant religious life in Africa provides an additional element of the process by which institutions become consolidated. This is the process of gradual embedding. The model of Protestant congregationalism already existed in the British and American contexts from which most missionaries came. But for congregational religion to take root in Africa, it had to be enacted as a coherent, lived practice. It then was embraced by larger numbers of people who - in a process parallel to that Thelen describes - came to see how its forms could serve their interests, both spiritual and material. But then the institution went through another critical phase in which it was "indigenized," reappropriated in ways that made it both organizationally and symbolically closer to African experience. The Zionist churches recreated forms of prophecy and healing that were recognizable culturally, but that also invoked spiritual power in ways that had traditionally animated collectivities beyond clan and village communities (Feierman 1999). Finally, those new sources of power and inspiration made the potential value of an organizational resource outside village and lineage ties available to the vast majority of ordinary Africans.

The role of incentives becomes especially clear in institutional contexts in which both types of organizations - Protestant congregations and NGOs - overlap: the many Protestant faith-based organizations (FBOs) which have been founded over the last decades and which have become part of the world of development work (Burchardt 2014, 2015). Initially, these FBOs often grew out of bottom-up processes of resource mobilization and were driven by distinctly religious and culturally resonant ideas about modernity and progress. To some degree, FBOs have worked to further "embed" the organizational practices of NGOs locally. However, the more Protestant congregations emulated NGOs' organizational templates and practices (usually in an effort to "grow") and thus operated as NGOs, the more they began to be driven by the same sort of incentive system. Becoming NGOs meant that Protestant congregations began to adopt principles of patronage, orienting themselves towards external resources and thus promoting incentives that undercut sustainability and horizontal replication.

Supply-side influences on religious vitality Our findings also speak to larger debates in the sociology of religion about "supply side" vs. "demand side" explanations of religious change. We recognize the new "demands" that congregational Protestantism met: both the need for powerful new symbols and rituals that could cope with the growing power of forces that operated beyond the practical and spiritual world of the 
village, and the practical need for new forms of solidarity and cooperation that could link people beyond the confines of kin, clan and village ties. But these new "needs" could not become effective without an institution to meet them. Our analysis weighs on side of "supply-side" factors not because rational-choice or "market" models of religious adherence are persuasive, but because incentives that create strong motives for replicating an institutional form, and that reward those who are successful, imbed the institution in such a way that its reward system and its moral claims are aligned (White and White 1965; Mohr and White 2008; Scott 2008). In the Protestant congregation, those who claimed spiritual power to prophesy and to heal could provide two kinds of rewards to their followers. They could provide the immediate emotional rewards of fellowship and the collective effervescence that conquered both physical and emotional troubles. At the same time, the congregations they founded also provided the practical rewards of added contacts, information and help that flowed from the congregation, even as these leaders demonstrated their worth by the rewards they accumulated as gifts and assistance from their congregants. Spiritual power demonstrated and was demonstrated by the power to form a congregation around one's message and to bring blessings on its members.

Cultural translation Finally, Protestant congregationalism could really take-off only when Christianity was reappropriated in symbolic terms that made local sense. The process of cultural appropriation thus involves adaptation to locally meaningful images of collective life, especially, we would argue, the reanimation of images of the sacredimages that describe and animate the power of collective life - so that they can attract local adherents. The African Independent churches of the third wave of Christianity's spread in Africa offered both healing and continuing prophecy, elements that had been central to indigenous African religious systems (Horton 1971; Horton and Peel 1976). Nonetheless, African Independent churches deviated from indigenous African systems in critical ways. They offered a form of institutional life - the independent congregation - that was tied neither to village nor lineage and kinship structures. African churches offered, and continue to offer, all manner of healing, from healing physical illness, to exorcism of various forms of spirit possession, to healing of moral and emotional distress (Comaroff 1985; Fields 1985; Dilger 2007; Pype 2011; Werbner 2011). But the new institutional form in which prophecy and healing could be given potent new Christian meaning did thrive and continues to explode outside denominations and other boundaries with the rise of Pentecostal and ever new variants of African independent churches (for an overview, see B. Meyer 2004). This is not primarily a matter of syncretism between Christian symbols and rituals and those of African indigenous religions. Indeed, as we have argued, the early missionaries often sought to extirpate all traces of African religious symbols, of ancestor worship, of witchcraft, from their churches. Even now, Protestant pastors frequently reject all forms of traditional healing, witchcraft, and ancestor worship, insisting on the power of Jesus to defeat all demons and witches. Nonetheless, to take root and thrive, imported institutions have to be able to animate collective life, and to do so, they must embody elements of the sacred (Swidler 2010). This whiff of the sacred has animated the other major institutional form that has spread (also from missionary roots) around the world: that of education, with its powerful mystique (Frank and Meyer 2007; Frye 2012; Woodberry 2012). In something like the way Clifford Geertz (1968) described for the 
coming of Islam to Morocco and Indonesia, the full incorporation of a new institutional form into an existing society involves a deep, innovative reconstitution of meanings that animates the new institutional form with sacred power.

Acknowledgements We would like to thank Claude Fischer, Arlie Hochschild, Tabitha Kanogo, Matthias Koenig, John Meyer, Susan Watkins, Bob Woodberry, Daniel Wroe, and colleagues at Berkeley, the Canadian Institute for Advanced Research, Leipzig University, the Max Planck Institute for the Study of Religious and Ethnic Diversity Göttingen, University of California Irvine, University of Chicago, Harvard University, University of Notre Dame, University of Virginia, The World Bank, the Graduate Theological Union, and two anonymous reviewers for advice and feedback on earlier versions of the paper.

Funding Information Open Access funding provided by Projekt DEAL.

Open Access This article is licensed under a Creative Commons Attribution 4.0 International License, which permits use, sharing, adaptation, distribution and reproduction in any medium or format, as long as you give appropriate credit to the original author(s) and the source, provide a link to the Creative Commons licence, and indicate if changes were made. The images or other third party material in this article are included in the article's Creative Commons licence, unless indicated otherwise in a credit line to the material. If material is not included in the article's Creative Commons licence and your intended use is not permitted by statutory regulation or exceeds the permitted use, you will need to obtain permission directly from the copyright holder. To view a copy of this licence, visit http://creativecommons.org/licenses/by/4.0/.

\section{References}

Bartley, T. (2007). How foundations shape social movements: The construction of an organizational field and the rise of Forest certification. Social Problems, 54(3), 229-255.

Bayart, J. F. (1993). The state in Africa: The politics of the belly. New York: Longmans Publishing.

Beidelman, T. O. (1982). Colonial evangelism: A socio-historical study of an east African Mission at the grassroots. Bloomington: Indiana University Press.

Boli, J. (1979). The ideology of expanding state Authority in National Constitutions, 1870-1970. In J. W. Meyer \& M. T. Hannan (Eds.), National development and the world system (pp. 222-249). Chicago: University of Chicago Press.

Bornstein, E. (2005). The Spirit of development: Protestant NGOs, morality, and economics in Zimbabwe. Stanford: Stanford University Press.

Burchardt, M. (2013). Faith-based humanitarianism: Organizational change and everyday meanings in South Africa. Sociology of Religion, 74(1), 30-55.

Burchardt, M. (2014). AIDS activism in the age of ARV treatment in South Africa: Christianity, resource mobilisation and the meanings of engagement. Journal of Southern African Studies, 40(1), 59-74.

Burchardt, M. (2015). Faith in the time of AIDS: Religion, biopolitics and modernity in South Africa. Basingstoke: Palgrave Macmillan.

Bushman, R. L. (1967). From puritan to Yankee. Cambridge: Harvard University Press.

Cabrita, J. (2014). Text and Authority in the South African Nazaretha Church. New York: Cambridge University Press.

Campbell, D. E., \& Putnam, R. D. (2010). American grace: How religion divides and unites us. New York: Simon and Schuster.

Casey, K., Rachel, G., \& Edward, M. (2012). Reshaping institutions: Evidence on aid impacts using a Preanalysis plan. The Quarterly Journal of Economics, 127(4), 1755-1812.

Chabal, P. (2009). Africa: The politics of suffering and smiling. London: Zed Books.

Chabal, P., \& Daloz, J. P. (1999). Africa works: Disorder as political instrument. Bloomington: Indiana University Press.

Chaves, M., \& Gorski, P. S. (2001). Religious pluralism and religious participation. Annual Review of Sociology, 27, 261-281. 
Chen, C. (2008). Getting saved in America: Taiwanese immigration and religious experience. Princeton: Princeton University Press.

Comaroff, J. (1985). Body of power, Spirit of resistance. Chicago: University of Chicago Press.

Comaroff, J. L. (1989). Images of empire, contests of conscience: Models of colonial domination in South Africa. American Ethnologist, 16(4), 661-685.

Comaroff, J. \& Comaroff, J. L. (1997). Of revelation and revolution. The Dialectics of Modernity on a South African Frontier. Vol. II. Chicago: Chicago University Press.

Cooley, A. (2010). Outsourcing authority: How project contracts transform global governance networks. In D. D. Avant, M. Finnemore, \& S. K. Sell (Eds.), Who governs the globe? (pp. 238-265). New York: Cambridge University Press.

Dangaremba, T. (1988). Nervous conditions. London: Women's Press.

Dilger, H. (2007). Healing the wounds of modernity: Salvation, community and care in a Neo-Pentecostal Church in Dar Es Salaam, Tanzania. Journal of Religion in Africa 37(1), 59-83.

Dilger, H., Burchardt, M., \& van Dijk, R. (2010). Introduction-The redemptive moment: HIV treatments and the production of new religious spaces. African Journal of AIDS Research, 9(4), 373-383.

Dobbin, F., Simmons, A. B., \& Garrett, G. (2007). The global diffusion of public policies: Social construction, coercion, competition, or learning? Annual Review of Sociology, 33, 449-472.

Eisenstadt, S. N. (1978). Revolution and the transformation of societies: A comparative study of civilizations. New York: Free Press.

Englund, H. (2001). The quest for missionaries: Transnationalism and township Pentecostalism in Malawi. In A. Corten \& R. Marshall-Fratani (Eds.), Between babel and Pentecost: Transnational Pentecostalism in Africa and Latin America (pp. 235-255). Bloomington: Indiana University Press.

Englund, H. (2003). Christian dependency and global membership: Pentecostal extraversions in Malawi. Journal of Religion in Africa, 33(1), 83-111.

Englund, H. (2006). Prisoners of freedom: Human rights and the African poor. Cambridge: Cambridge University Press.

Etherington, N. (1979). The historical sociology of independent churches in South East Africa. Journal of Religion in Africa, 10(Fasc. 2), 108-126.

Etherington, N. (2001). The great treks: The transformation of southern Africa, 1815-1854. Longman Publishing Group.

Evans, P. B., \& Rauch, J. E. (1999). Bureaucracy and growth: A cross-National Analysis of the effects of 'Weberian' state structures on economic growth. American Sociological Review, 64(5), 748-765.

Fearon, J. D., Humphreys, M., \& Weinstein, J. M. (2009). Can development aid contribute to social cohesion after civil war? Evidence from a field experiment in post-conflict Liberia. The American Economic Review, 99(2), 287-291.

Feierman, S. (1999). Colonizers, scholars, and the creation of invisible histories. In V. E. Bonnell \& L. Hunt (Eds.), Beyond the cultural turn (pp. 182-216). Berkeley: University of California Press.

Fields, K. E. (1985). Revival and rebellion in colonial Central Africa. Princeton: Princeton University Press.

Finke, R., \& Stark, R. (1992). The churching of America, 1776-1990: Winners and losers in our religious economy. New Brunswick: Rutgers University Press.

Fischer, C. S. (2010). Made in America: A social history of American culture and character. Chicago: University of Chicago Press.

Fisman, R., \& Miguel, E. (2008). Economic gangsters: Corruption, violence, and the poverty of nations. Princeton: Princeton University Press.

Fligstein, N., \& McAdam, D. (2012). A theory of Fields. New York: Oxford University Press.

Frank, D. J., \& Meyer, J. W. (2007). University expansion and the knowledge society. Theory and Society, 36(4), 287-311.

Freeman, D. (2012). The Pentecostal ethic and the Spirit of development. In D. Freeman (Ed.), Pentecostalism and development: Churches, NGOs and social change in Africa (pp. 1-38). New York: Palgrave Macmillan.

Frye, M. (2012). Bright futures in Malawi's new Dawn: Educational aspirations as assertions of identity. American Journal of Sociology, 117(6), 1565-1624.

Frye, M. (2013). Sexual behavior and scholastic success: Moral codes and behavioral outcomes in Malawi. Doctoral dissertation. University of California, Berkeley, 2013.

Gaitskell, D. (2000). Hot meetings and hard kraals: African Biblewomen in Transvaal Methodism. Journal of Religion in Africa, 30(3), 277-309.

Geertz, C. (1968). Islam observed: Religious development in Morocco and Indonesia. New Haven: Yale University Press. 
Ghodsee, K. (2006). Nongovernmental ogres? How feminist NGOs undermine women in postsocialist Eastern Europe. International Journal of Not-for-Profit Law 8(3), 44-59.

Gifford, P. (1994). Some recent developments in African Christianity. African Affairs, 93, 513-534.

Gorski, P. S. (2003). The disciplinary revolution: Calvinism and the rise of the state in early modern Europe. Chicago: University of Chicago Press.

Granovetter, M. (1985). Economic action and social structure: The problem of Embeddedness. American Journal of Sociology, 91(3), 481-510.

Hall, P. A., \& Soskice, D. (Eds.). (2001). Varieties of capitalism: The institutional foundations of comparative advantage. New York: Oxford University Press.

Hall, P., \& Taylor, R. C. R. (1996). Political science and the three new institutionalisms. Political Studies, 44, 936-957.

Hammack, D., \& Heydemann, S. (Eds.). (2009). Globalization, philanthropy, and civil society. Projecting institutional logics abroad. Bloomington \& Indianapolis: Indiana University Press.

Holzer, E. (2013). What happens to law in a refugee camp? Law and Society Review, 47(4), 837-872.

Horton, R. (1971). African conversion. Africa, 41(2), 85-108.

Horton, R., \& Peel, J. D. Y. (1976). Conversion and confusion: A rejoinder on Christianity in eastern Nigeria. Canadian Journal of African Studies/Revue Canadienne des Études Africaines, 10(3), 481-498.

Jacoby, W. (2000). Imitation and politics: Redesigning modern Germany. Ithaca and London: Cornell University Press.

Jalali, R. (2013). Financing empowerment? How foreign aid to southern NGOs and social movements undermines grass-roots mobilization. Sociology Compass, 7(1), 55-73.

Jepperson, R. L., \& Meyer, J. W. (2011). Multiple levels of analysis and the limitations of methodological individualisms. Sociological Theory, 29(1), 54-73.

Jones, B. (2012). Pentecostalism, development NGOs and meaning in eastern Uganda. In D. Freeman (Ed.), Pentecostalism and development: Churches, NGOs and social change in Afric (pp. 181-202). Basingstoke: Palgrave Macmillan.

Kiernan, J. P. (1995). The African independent churches. In M. Prozesky \& J. W. de Gruchy (Eds.), Living Faiths in South Africa (pp. 116-128). Cape Town: David Philip.

Krause, M. (2014). The good project: Humanitarian relief NGOs and the fragmentation of reason. Chicago: University of Chicago Press.

Laitin, D. D. (1986). Hegemony and Culture: Politics and Change among the Yoruba: University of Chicago Press.

Landau, P. (1995). "The realm of the word." Language, gender and Christianity in a southern African kingdom. London and Cape Town: Heinemann and David Philip Publishers.

Landau, P. (1999). 'Religion' and Christian conversion in African history: A new model. Journal of Religious History, 23(1), 8-30.

Luke, N., \& Watkins, S. C. (2002). Reactions of developing-country elites to international population policy. Population and Development Review 28(4), 707-733.

Mahoney, J., \& Thelen, K. (Eds.). (2010). Explaining institutional change: Ambiguity, agency, and power. Cambridge: Cambridge University Press.

Manglos, N. D. (2010). Born again in Balaka: Pentecostal versus Catholic narratives of religious transformation in rural Malawi. Sociology of Religion, 71(4), 409-431.

Manglos, N. (2011). Brokerage in the sacred sphere: Religious leaders as community problem solvers in rural Malawil. Sociological Forum, 26(2), 3343-3355.

Manji, F., \& O'Coill, C. (2002). The missionary position: NGOs and development in Africa. International Affairs, 78(3), 567-583.

Mansuri, G., \& Rao, V. (2012). Localizing development: Does participation work? New York: World Bank Publications.

Mansuri, G., \& Rao, V. (2013). Can participation be induced? Some evidence from developing countries 1. Critical Review of International Social and Political Philosophy, 16(2), 284-304.

Marshall, R. (2009). Political Spiritualities. Chicago: The University of Chicago Press.

McDonnell, E. M. (2020). Patchwork leviathan: Pockets of bureaucratic effectiveness in developing states. Princeton: Princeton University Press.

McGinnis, M. D. (2007). From self-reliant churches to self-governing communities: Comparing the indigenization of Christianity and democracy in sub-Saharan Africa. Cambridge Review of International Affairs, 20(3), 401-416.

Merry, S. E. (2006). Human Rights and Gender Violence: Translating International Law into Local Justice: University of Chicago Press. 
Meyer, J. W. (1987). The world polity and the Authority of the Nation State. In G. M. Thomas, J. W. Meyer, F. O. Ramirez, \& J. Boli (Eds.), Institutional structure: Constituting state, society, and the individual (pp. 41-70). Beverly Hills: Sage.

Meyer, B. (1997). Christian mind and worldly matters religion and materiality in nineteenth-century Gold Coast. Journal of Material Culture, 2(3), 311-337.

Meyer, B. (1999). Translating the devil: Religion and modernity among the ewe in Ghana. Edinburgh: Edinburgh University Press.

Meyer, B. (2004). Christianity in Africa: From African independent to Pentecostal-charismatic churches. Annual Review of Anthropology, 33, 447-474.

Meyer, J. W., \& Rowan, B. (1977). Institutionalized organizations: Formal structure as myth and ceremony. American Journal of Sociology, 83(2), 340-363.

Meyer, J. W., Boli, J., Thomas, G. M., \& Ramirez, F. O. (1997). World society and the nation state. American Journal of Sociology, 103(1), 144-181.

Mohr, J. W., \& White, H. C. (2008). How to model an institution. Theory and Society, 37(5), 485-512.

Morfit, S. (2011). AIDS is money: How donor preferences reconfigure local realities. World Development, 39(1), 64-76.

Nelson, S., \& Gorski, P. S. (2014). Conditions of religious belonging: Confessionalization, DeParochialization, and the euro-American divergence. International Sociology, 29(1), 3-21.

Ostrom, E. (1990). Governing the commons: The evolution of institutions for collective action. Cambridge: Cambridge University Press.

Palmer, D. A., Jennings, P. D., \& Zhou, X. (1993). Late adoption of the multidivisional form by large U.S. corporations: Institutional, political, and economic accounts. Administrative Science Quarterly, 38(1), 1001-1031.

Peel, J. D. Y. (1968). Aladura: A religious movement among the Yoruba. London: Oxford University Press.

Pew Research Center. (2012). Where Christians live: Large global shifts in sast century. https://www. pewresearch.org/fact-tank/2012/01/05/wherechristians-live-large-global-shifts-in-last-century/.

Pfeiffer, J. (2004). Civil society, NGOs, and the holy Spirit in Mozambique. Human Organization, 63(3), 359372.

Pigg, S. L. (2005). Globalizing the facts of life. In S. L. Pigg \& V. Adams (Eds.), Sex in Development. Science, Sexuality, and Morality in Global Perspective (pp. 39-65). Durham \& London: Duke University Press.

Pype, K. (2011). Confession cum deliverance: In/Dividuality of the subject among Kinshasa's born-again Christians. Journal of Religion in Africa, 41(3), 280-310.

Sanneh, L. (2001). A resurgent Church in a Troubled Continent: Review essay of Bengt Sundkler's History of the Church in Africa. International Bulletin of Missionary Research, 25(3), 113-118.

Scherz, C. (2014). Having people, having heart: Charity, sustainable development, and problems of dependence in Central Uganda. Chicago: University of Chicago Press.

Schmidt, E. (1992). Peasants, traders, and wives: Shona women in the history of Zimbabwe, 1870-1939. Portsmouth, NH: Heineman.

Scott, W. R. (2008). Institutions and organizations: Ideas and interests. Thousand Oaks: Sage Publications.

Smith, D. J. (2003). Patronage, per diems and 'the workshop mentality': The practice of family planning programs in southeastern Nigeria. World Development, 31(4), 703-715.

Stamatov, P. (2013). The origins of global humanitarianism: Religion, empires, and advocacy. New York: Cambridge University Press.

Stanczak, G. C., Miller, D. E., \& Dyrness, G. R. (2006). Spiritually engaged development: Faith and community transforming Tanzania. Los Angeles: Center for Religion and Civic Culture, University of Southern California.

Strang, D. (1990). From dependency to sovereignty: An event history analysis of decolonization 1870-1987. American Sociological Review, 55(6), 846-860.

Strayer, R. W. (1978). The making of Mission communities in East Africa: Anglicans and Africans in colonial Kenya, 1875-1935. Albany: SUNY Press.

Stuart, R. (1979). Anglican missionaries and a Chewa 'Dini': Conversion and rejection in Central Malawi. Journal of Religion in Africa, 10(1), 46-69.

Sundkler, B. (1961). Bantu prophets in South Africa. Cambridge: James Clarke \& Co..

Swidler, A. (2009). Dialectics of patronage: Logics of accountability at the African AIDS-NGO Interface. In S. Heydemann \& D. C. Hammack (Eds.), Globalization, philanthropy, and civil society: Projecting institutional logics abroad (pp. 192-200). Bloomington: Indiana University Press.

Swidler, A. (2010). The return of the sacred: What African chiefs teach us about secularization. Sociology of Religion, 71(2), 157-171. 
Swidler, A., \& Watkins, S. C. (2009). "Teach a man to fish": The sustainability doctrine and its social consequences. World Development, 37(7), 1182-1196.

Swidler, A., \& Watkins, S. C. (2017). A fraught embrace: The romance and reality of AIDS altruism in Africa. Princeton: Princeton University Press.

Tavory, I., \& Eliasoph, N. (2013). Coordinating futures: Toward a theory of anticipation. American Journal of Sociology, 118(4), 908-942.

Thompson, E. P. (1963). The making of the English working class. New York: Pantheon Books.

Thelen, K. (2004). How institutions evolve: The political economy of skills in Germany, Britain, the United States and Japan . Cambridge: Cambridge University Press.

Tolbert, P. M., \& Zucker, L. G. (1983). Institutional sources of change in the formal structure of organizations: The diffusion of civil service reform, 1880-1935. Administrative Science Quarterly, 28, 22-39.

Trinitapoli, J., \& Weinreb, A. (2012). Religion and AIDS in Africa. New York: Oxford University Press.

Troeltsch, E. (1992) [1912]. The social teaching of the Christian churches. Chicago: University of Chicago Press.

Tyrell, H. (2004). Weltgesellschaft, Weltmission und religiöse Organisationen. In A. Bogner, B. Holtwick, \& H. Tyrell (Eds.), Weltmission und religiöse Organisationen (pp. 13-136). Würzburg: Ergon.

Van Binsbergen, W. M. J. (2004). Challenges for the sociology of religion in the African context: Prospects for the next 50 years. Social Compass, 51(1), 85-98.

Villa-Vicencio, C. (1995). Mission Christianity. In M. Prozesky \& J. W. de Gruchy (Eds.), Living Faiths in South Africa (pp. 45-71).

Wallace, T., Bornstein, L., \& Chapman, J. (2007). The aid chain: Coercion and commitment in development NGOs. Rugby: Intermediate Technology Publications.

Walzer, M. (1965). The revolution of the saints: A study in the origins of radical politics. Cambridge: Harvard University Press.

Warner, R. S. (1993). Work in Progress toward a new paradigm for the sociological study of religion in the United States. American Journal of Sociology, 98(5), 1044-1093.

Watkins, S. C., Swidler, A., \& Hannan, T. (2012). Outsourcing social transformation: Development NGOs as organizations. Annual Review of Sociology, 38, 285-315.

Weber, M. (1946). Religious rejections of the world and their directions. In H. H. Gerth \& C. W. Mills (Eds.), From max Weber: Essays in sociology (pp. 323-359). New York: Oxford University Press.

Werbner, R. (2011). Holy hustlers, schism, and prophecy: Apostolic reformation in Botswana. Berkeley: University of California Press.

White, L. (1987). Magomero: Portrait of an African Village: Cambridge University press.

White, H. C., \& White, C. A. (1965). Canvases and careers: Institutional change in the French painting world. New York: John Wiley and Sons.

Wilson, M. (2009). Reaction to conquest: Effects of contact with Europeans on the Pondo of South Africa. Münster: LIT Verlag.

Woodberry, R. D. (2012). The missionary roots of Liberal democracy. American Political Science Review, $106(2), 244-274$.

Publisher's note Springer Nature remains neutral with regard to jurisdictional claims in published maps and institutional affiliations.

Marian Burchardt is Professor of Sociology at Leipzig University and Co-Director of the Leipzig Lab "Global Health." His book, Faith in the Time of AIDS: Religion, Biopolitics and Modernity in South Africa (Palgrave Macmillan 2015) is an ethnography of the entanglements of religion, sexuality, and biomedicine in South Africa's fight against the HIV epidemic. His current work focuses on new health infrastructures and urban religion.

Ann Swidler is Professor of the Graduate School at the University of California, Berkeley. Her most recent book (with Susan Cotts Watkins) is A Fraught Embrace: The Romance and Reality of AIDS Altruism in Africa (Princeton 2017). Her current project, Social Ecologies of Religion in Malawi, examines how interconnections among religious congregations, chiefs, and NGOs influence the production of collective goods. 